\title{
AMMONIA PLUS ANOTHER FACTOR ARE NECESSAR Y FOR DIFFERENTIATION IN SUBMERGED CLUMPS OF DICTYOSTELIUM
}

\author{
JOHN STERNFELD AND CHARLES N. DAVID \\ Department of Molecular Biology, Albert Einstein College of Medicine, \\ Bronx, New York I046I, U.S.A.
}

\begin{abstract}
SUMMARY
Differentiation of Dictyostelium amoebae can occur in submerged clumps of cells; under an oxygen atmosphere mature stalk cells and spores form, as has been shown in previous work. This report shows that at least 2 factors are released by the cells under these conditions, and that both, together, are required for differentiation of stalk cells and spores. One of the factors is ammonia $\left(\mathrm{NH}_{3}+\mathrm{NH}_{4}{ }^{+}\right)$. The other factor(s) is heat stable and dialysable but has not yet been further characterized. The factors can be collected in conditioned medium and, when added to cells, stimulate differentiation. Conditioned medium loses its biological activity upon the removal of the $\mathrm{NH}_{3}+\mathrm{NH}_{4}+$. When $\mathrm{NH}_{3}+\mathrm{NH}_{4}+$ is added back, activity is restored. Because $\mathrm{NH}_{3}+\mathrm{NH}_{4}{ }^{+}$, alone, has no activity, a second factor(s) in the conditioned medium must be required for differentiation. It is also shown that calcium inhibits differentiation in submerged clumps and that in calcium-free medium the timing of differentiation is essentially the same as under aerial conditions.
\end{abstract}

\section{INTRODUCTION}

Vegetative amoebae of the cellular slime moulds differentiate to form either stalk cells or spores in the fruiting body. Endogenous factors must exist to control the timing of differentiation and the proportions of stalk cells and spores. For stalk differentiation 2 such factors, cAMP and a second, as yet unidentified, factor, have been shown to be important (Bonner, 1970; Town, Gross \& Kay, 1976).

Recently, it has been shown that differentiation of Dictyostelium amoebae can occur in submerged balls of cells or clumps (Sternfeld \& Bonner, I977; Takeuchi, Hayashi \& Tasaka, 1977; Forman \& Garrod, 1977). In one system, mature stalk cells and spores were formed when the cell suspension was agitated under a pure oxygen atmosphere (Sternfeld \& Bonner, 1977). This technique is particularly useful for biochemical studies of factors controlling differentiation because the chemical environment of the cells can be varied throughout development, and cell products, active in development, can be isolated easily.

This paper reports that 2 factors are required for differentiation of stalk cells and spores in submerged clumps. One factor is ammonia; a second heat stable, dialysable factor(s) has not yet been characterized. Both factors, together, are necessary for differentiation under submerged conditions. It is also shown that calcium inhibits differentiation and in calcium-free medium the timing of differentiation in submerged clumps is essentially the same as under aerial conditions. 


\section{MATERIALS AND METHODS}

\section{Growth conditions}

Dictyostelium discoideum (strain $\mathrm{NC}_{-4}$, haploid) amoebae were grown in liquid culture on Klebsiella pneumonia (strain 29). The bacteria were suspended in $50 \mathrm{~mm}$ potassium phosphate buffer $(\mathrm{pH} 6 \cdot 2)$ at an optical density $\left(55^{\circ} \mathrm{nm}\right)$ of $5^{\circ}$. The bacterial suspensions were inoculated with spores and, after approximately $36 \mathrm{~h}$ at $22^{\circ} \mathrm{C}$, the amoebae cleared the bacteria. The cells were harvested and washed in either standard salt solution (1० $\mathrm{mm} \mathrm{NaCl}$, ro $\mathrm{mM} \mathrm{KCl}$, $2.7 \mathrm{mM} \mathrm{CaCl}, \mathrm{pH} 6.4-6.6$; Bonner, 1947 ) or $17 \mathrm{~mm}$ sodium potassium phosphate buffer (pH 6.6).

\section{Preparation of conditioned medium}

Conditioned medium was prepared by incubating cells (harvested at $36 \mathrm{~h}$ ) in either standard salt solution or $17 \mathrm{mM}$ phosphate buffer. Routinely $200-300 \mathrm{ml}$ of medium containing $1 \times 10^{8}$ cells per $\mathrm{ml}$ were shaken in a 2 or 3 l. flask on a rotary shaker table at about $75 \mathrm{rev} / \mathrm{min}$. It did not matter whether the atmosphere above the cell suspension was air or $100 \%$ oxygen. After $48-72 \mathrm{~h}$ the cells were removed by a $10-$ min centrifugation at 10000 $\mathrm{g}$. The supernatant, pale yellow in colour, constituted conditioned medium and was stored frozen.

\section{Assay for differentiation}

Conditioned medium was assayed by its effect on differentiation in submerged clumps. Cells, after clearing the bacteria were allowed to starve for 8-10 h before they were harvested, washed and resuspended in $17 \mathrm{~mm}$ phosphate buffer or standard salt solution. One millilitre of the cell suspension at $5 \times 10^{6}$ cells $/ \mathrm{ml}$ was put into each well (Dispo-Tray, Linbro Chemical Co.). The wells were placed in a covered plastic box through which roo \% oxygen (saturated with water) was constantly flowing at a rate which replaced the volume of the box every ro min. The box, which leaked enough so that pressure did not build up inside, was shaken at I 50 rev $i$ min on a rotary shaker table.

To score stalk and spore differentiation the clumps which formed in the wells were removed to a slide after 20-2I h in $17 \mathrm{mM}$ phosphate buffer (or $72 \mathrm{~h}$ in standard salt solution) and thoroughly squashed under a coverslip. The amount of differentiation was judged by making an estimate of the percentage of stalk cells and spores relative to the total number of cells. The activity of conditioned medium was titred by making 2 -fold serial dilutions. The highest dilution (lowest concentration) which had a significant amount of differentiation (5\% spores) indicated the strength of the activity.

\section{Ammonia assay}

Ammonia $\left(\mathrm{NH}_{3}+\mathrm{NH}_{4}{ }^{+}\right)$was determined by Nessler's reagent. Procedures were modified from Fischer \& Peters (1968). The $\mathrm{pH}$ of a $10 \mathrm{~mm}$ solution of $\mathrm{HgI}_{2} \cdot 2 \mathrm{KI}$ was adjusted to $12 \cdot 8$. I $00 \mu \mathrm{l}$ of this solution were added to $\mathrm{I} \mathrm{ml}$ of the sample to be tested and after 2 min the absorbance at $375 \mathrm{~nm}$ was measured. Each sample was assayed with 3 dilutions over a 4-fold concentration range.

\section{RESULTS}

\section{Cells produce factors required for differentiation}

As previously reported, differentiation can be induced in submerged conditions in the presence of oxygen (Sternfeld \& Bonner, 1977). In these early experiments $5 \times 10^{6}$ cells were used and clumps of cells $100-200 \mu \mathrm{m}$ in diameter formed. Subsequently, it has been found that differentiation was enhanced at higher cell concentrations or in larger clumps. 
The effect of cell concentration on differentiation was systematically examined by placing clumps of various sizes in small volumes of standard salt solution. The clumps were made by drawing cells from a packed pellet of washed cells into a capillary pipette, extruding them into salt solution, and cutting defined lengths from the cylinder of cells. Clumps, containing from $\mathrm{r} \cdot 6 \times 10^{5}$ to $8.3 \times 10^{5}$ cells were put indi-

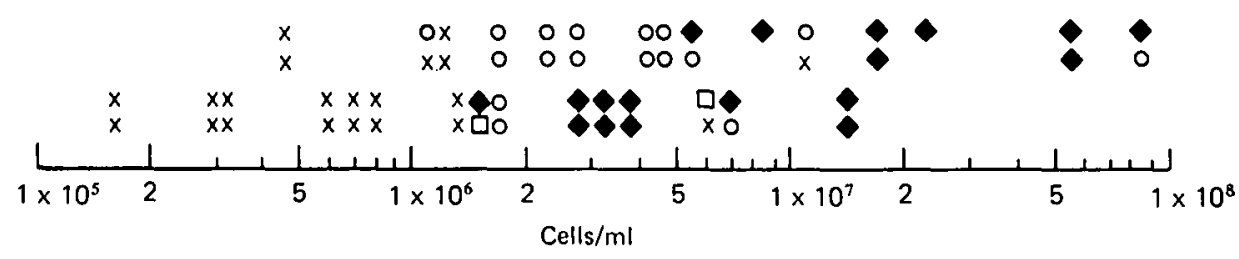

Fig. 1. Single clumps of $D$. discoideum cells were placed in small volumes of standard salt solution as described in the text. After $72 \mathrm{~h}, 2$ clumps from each concentration were squashed and examined for stalk cells and spores. Cell concentration is expressed on the log scale. Each symbol indicates the result from a single clump. The different symbols indicate which differentiated cell type was observed: $x$, no differentiated cells; $O$, stalk cells; $\square$, spores; $\$$, both stalk cells and spores. Two experiments are shown: the cell concentration of one ranged from $4.6 \times 10^{5}$ to $8.3 \times 10^{7}$ cells $/ \mathrm{ml}$ and of the other from $1.6 \times 10^{6}$ to $1.4 \times 10^{7}$ cells $/ \mathrm{ml}$.

Table I. Effects of calcium and cell concentration on differentiation

\begin{tabular}{|c|c|c|c|}
\hline & \multicolumn{3}{|c|}{$\mathrm{CaCl}_{2}$ concentration, $\mathrm{mM}$} \\
\hline & 0.027 & 0.27 & $2 \cdot 7$ \\
\hline $\begin{array}{l}\text { Threshold of stalk differentiation } \\
\text { (cells } / \mathrm{ml} \text { ) }\end{array}$ & $<2 \times 10^{5}$ & $3 \times 10^{5}$ & $3 \times 10^{6}$ \\
\hline $\begin{array}{l}\text { Threshold of spore differentiation } \\
\text { (cells } / \mathrm{ml} \text { ) }\end{array}$ & $3 \times 10^{5}$ & $6 \times 10^{5}$ & $>3 \times 10^{7}$ \\
\hline \multicolumn{4}{|c|}{$\begin{array}{l}\text { Single clumps were placed in various small volumes of a salt solution containing } \mathrm{IO} \mathrm{mM} \mathrm{NaCl} \\
\text { plus } \mathrm{IO} \mathrm{mM} \mathrm{KCl} \text {. } \mathrm{CaCl}_{2} \text { was added to the medium at the concentrations indicated. After } \\
72 \mathrm{~h} \text {, the clumps were examined for stalk cells and spores. The lowest cell concentration at } \\
\text { which stalk cells and spores differentiated is shown for each concentration of calcium. }\end{array}$} \\
\hline
\end{tabular}

vidually into volumes of standard salt solution from ro $\mu \mathrm{l}$ to I ml. Thus, cell concentrations ranged over nearly 3 orders of magnitude. These clumps were incubated in wells under an oxygen atmosphere for $7^{2} \mathrm{~h}$. Differentiation was sharply dependent on cell concentration (Fig. $\mathrm{I}$ ). Below $\mathrm{I}-2 \times 10^{6}$ cells per ml no differentiation occurred. Above this concentration stalk cells differentiated and at somewhat higher concentrations spores also formed. The lowest concentration at which spores first appeared varied in different experiments, but once present almost all of the higher cell concentrations also contained spores.

The cell concentration at which differentiation occurred depended on the calcium concentration. It was found that the greater the calcium concentration the greater the cell concentration needed to achieve differentiation (Table I). In addition, mature 
stalk and spores had formed by about $24 \mathrm{~h}$ in calcium-free medium, while, in the presence of calcium, differentiation of spores had just begun at $3^{6} \mathrm{~h}$ (Sternfeld \& Bonner, I977). Because of this inhibition of differentiation by calcium, all subsequent experiments were done in $17 \mathrm{~mm}$ phosphate buffer in the absence of calcium.

The above results suggested that stalk and spore differentiation are dependent on diffusible factor(s) secreted into the medium by the cells. A conditioned medium was prepared (see Materials and methods) and its effects on differentiation tested. Cells incubated in optimum concentrations of conditioned medium differentiate about $4-5 \mathrm{~h}$ earlier than cells incubated in fresh medium (Figs. 2, 3A). The differentiation observed in fresh medium under these assay conditions was due to the accumulation of endogenous factors during the assay. When clumps were periodically transferred to new fresh medium no differentiation was observed, even after $48 \mathrm{~h}$, while clumps transferred in conditioned medium differentiated with essentially the same kinetics as non-transferred clumps (Fig. $3^{\mathrm{B}}$ ).

These experiments clearly show that the factors secreted by cells and collected in conditioned medium are required for differentiation in submerged clumps. Because of the inconvenience of the transfer procedure, however, experiments were done routinely without transferring. The clumps were examined at about 20-2I $h$, at which time clumps in fresh medium had not differentiated, while clumps in conditioned medium contained from 20 to $50 \%$ spores (Fig. $3^{\mathrm{A}}$ ).

\section{Ammonia is one factor in conditioned medium}

The activity of conditioned medium was stable to $\mathrm{I} h$ of autoclaving and was quantitatively recovered outside a dialysis bag. A variety of substances known to be important in slime mould development, including phosphodiesterase, cAMP, cGMP, 5'AMP, adenosine, and ammonia (Bonner, 197I; Wurster, Schubiger, Wick \& Gerisch, 1977; Gregg, Hackney \& Krivanek, 1954), were tested for their ability to mimic or interfere with the stimulation of differentiation. Only ammonia $\left(\mathrm{NH}_{3}+\mathrm{NH}_{4}{ }^{+}\right)$showed any significant stimulation of differentiation. The compounds $\left(\mathrm{NH}_{4}\right)_{2} \mathrm{CO}_{3}, \mathrm{NH}_{4} \mathrm{Cl}$, and $\left(\mathrm{NH}_{4}\right)_{2} \mathrm{SO}_{4}$ usually stimulated low levels of differentiation in the concentration range of $4-\mathrm{IO} \mathrm{mM} \mathrm{NH}_{3}+\mathrm{NH}_{4}{ }^{+}$.

Conditioned medium was assayed with Nessler's reagent to determine if any $\mathrm{NH}_{3}+\mathrm{NH}_{4}{ }^{+}$was present. In all batches, ammonia was present at levels ranging from 24 to $30 \mathrm{~mm}$. These same batches had optimum activity in the 4 - and 8-fold dilutions which corresponds to $\mathrm{NH}_{3}+\mathrm{NH}_{4}{ }^{+}$concentrations of about 3-8 mM. Thus, biological activity occurred at dilutions of conditioned medium and concentrations of ammonia compounds which contain the same amount of $\mathrm{NH}_{3}+\mathrm{NH}_{4}{ }^{+}$. Furthermore, during the preparation of conditioned medium, samples were assayed for both $\mathrm{NH}_{3}+\mathrm{NH}_{4}+$ concentration and biological activity. The $\mathrm{NH}_{3}+\mathrm{NH}_{4}{ }^{+}$concentration and the biological activity rose roughly in parallel (Fig. 4) which is consistent with a role for $\mathrm{NH}_{3}+\mathrm{NH}_{4}{ }^{+}$as an active factor in conditioned medium.

Further evidence that $\mathrm{NH}_{3}+\mathrm{NH}_{4}+$ is an active factor was obtained by gently removing the $\mathrm{NH}_{3}+\mathrm{NH}_{4}{ }^{+}$from conditioned medium. At higher $\mathrm{pH}$ more ammonia is present in the volatile $\mathrm{NH}_{3}$ form. Thus, when conditioned medium was maintained 

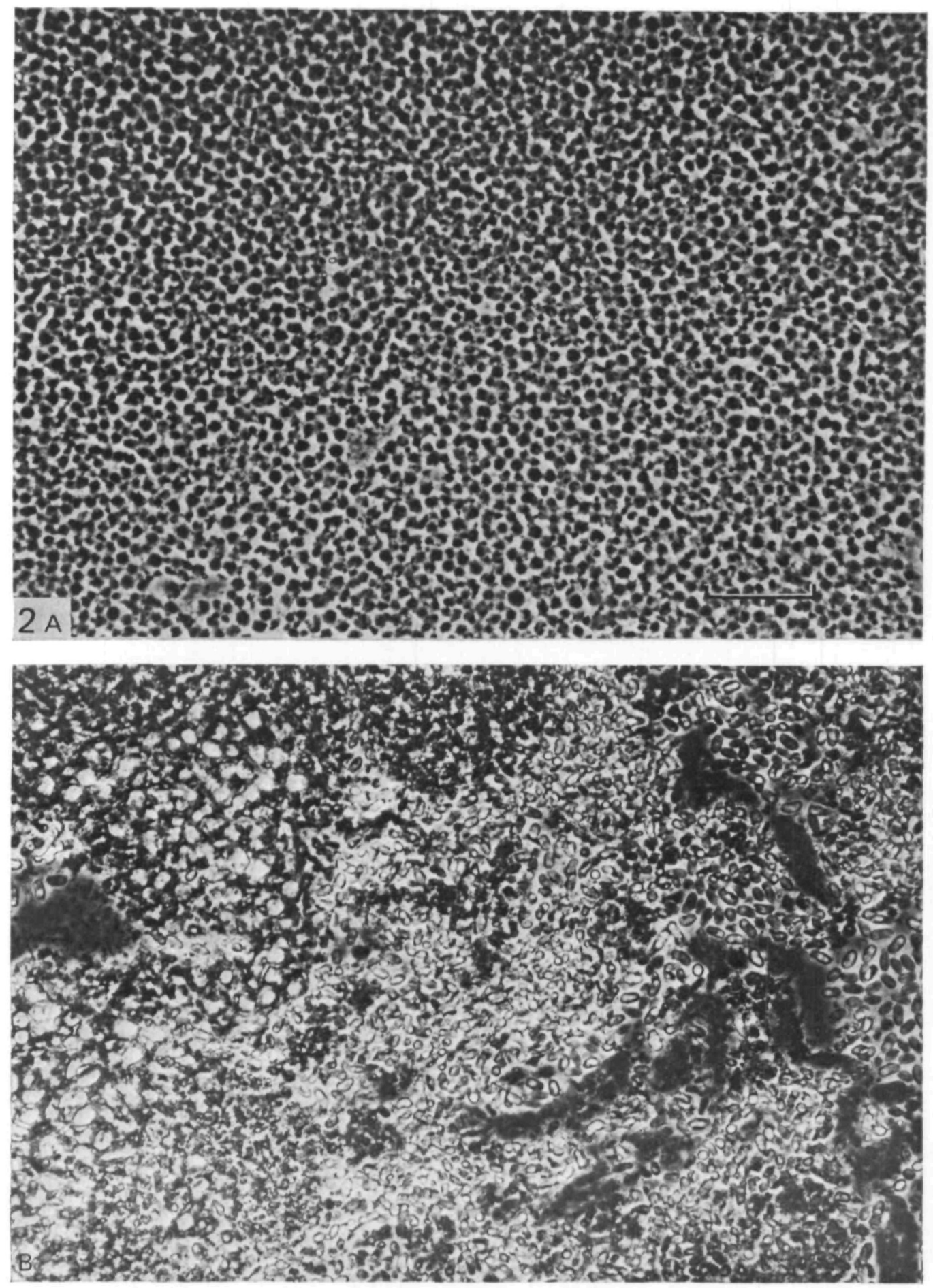

Fig. 2. $5 \times 10^{6}$ cells were added to $\mathrm{I} \mathrm{ml}$ of medium in Linbro wells. At $2 \mathrm{I} \mathrm{h}$ the clumps which formed were squashed on a slide and examined with phase microscopy. A, undifferentiated cells from fresh medium. B, vacuolated stalk cells and elliptical spores from an optimum concentration of conditioned medium. The bar represents $50 \mu \mathrm{m}$. 

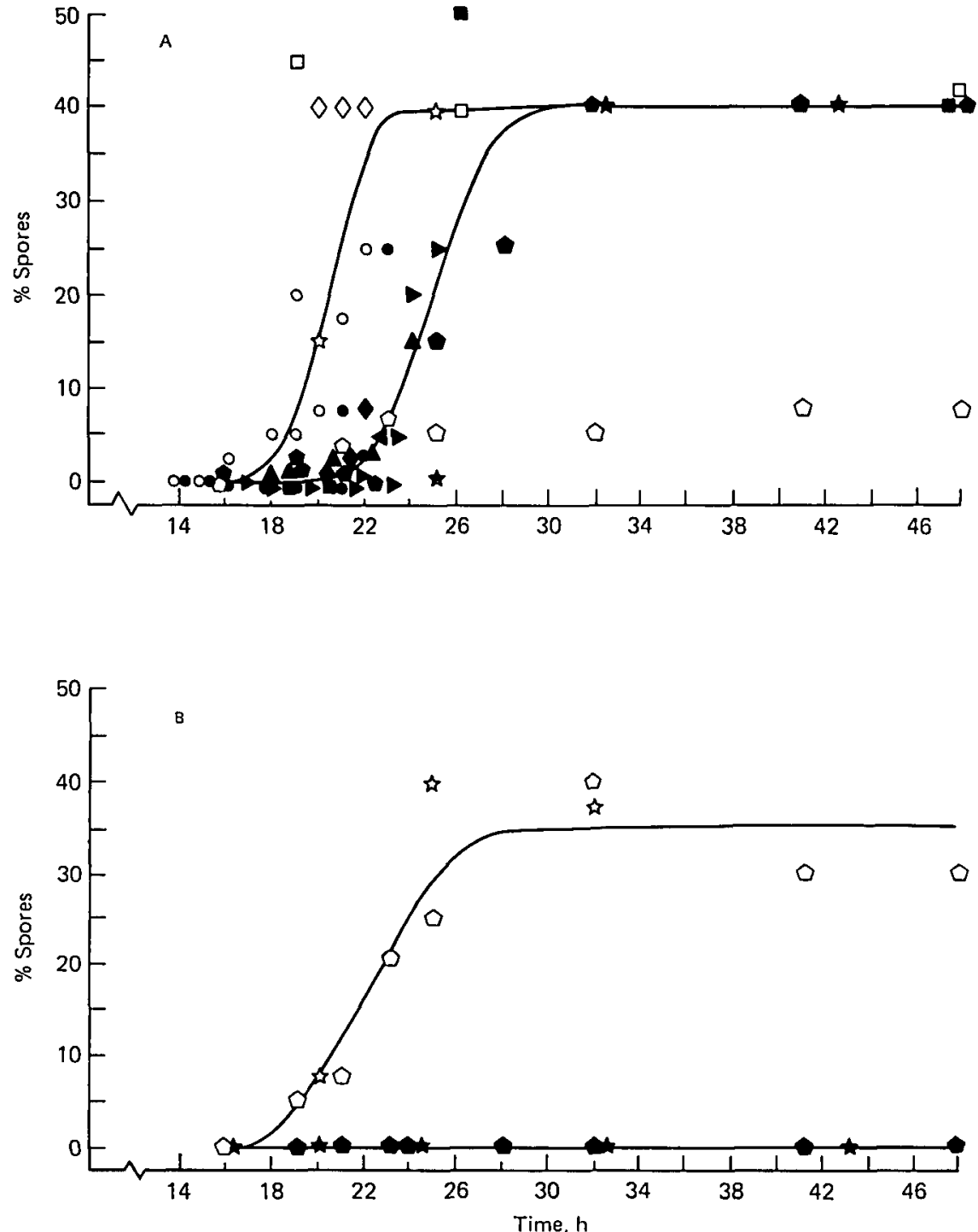

Fig. $3.5 \times 10^{6}$ cells were added to wells containing I $\mathrm{ml}$ of fresh $17 \mathrm{~mm}$ phosphate buffer (closed symbols) or I $\mathrm{ml}$ of conditioned medium in $17 \mathrm{~mm}$ phosphate buffer (open symbols). Clumps formed and at various times the contents of 2 wells of fresh and 2 wells of conditioned medium were examined for spore differentiation. The results of 7 experiments were depicted by variously shaped symbols. $A$, the clumps were incubated without transferring. B, the clumps were transferred every $8 \mathrm{~h}$ to new fresh or conditioned medium. In one experiment, the non-transferred clumps in conditioned medium did not differentiate (open pentagons, panel A). Such anomalous results were occasionally observed when too high a concentration of conditioned medium was tested (see Table 4 ). 
at $\mathrm{pH} 8.0$ and $55^{\circ} \mathrm{C}$ in an open container, the $\mathrm{NH}_{3}+\mathrm{NH}_{4}{ }^{+}$concentration was reduced about 50 -fold (to $0.4-0.8 \mathrm{~mm}$ ) in $2 \mathrm{~h}$. This treatment caused the loss of almost the entire biological activity (Table 2). Conditioned medium was also heated in a closed tube at $\mathrm{pH} 8.0$ or in an open Petri dish at $\mathrm{pH} 5.0(\mathrm{a} \mathrm{pH}$ at which only $0.01 \%$ of the

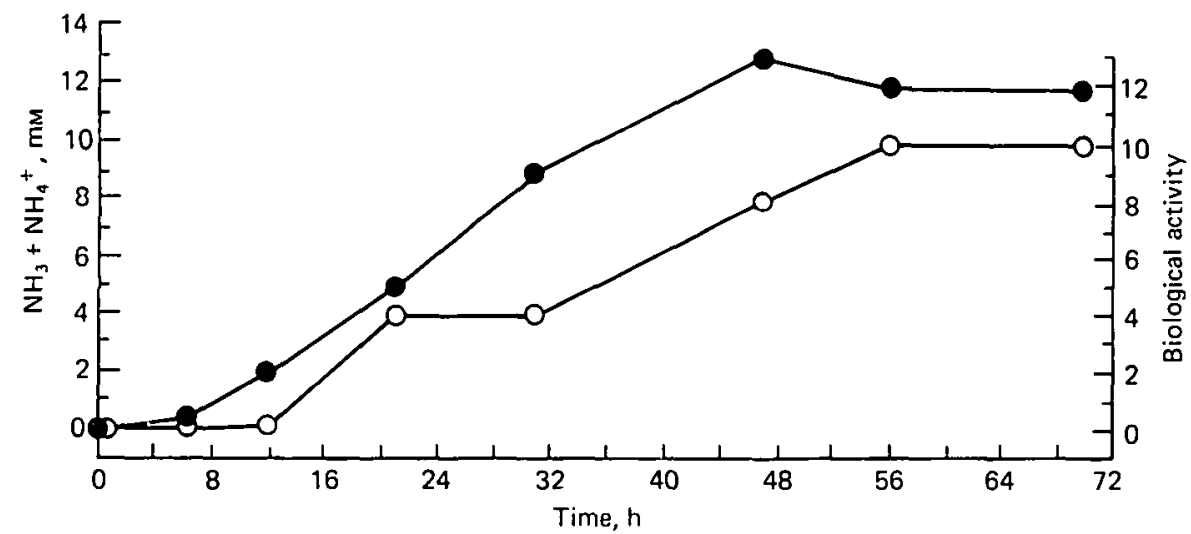

Fig. 4. $120 \mathrm{ml}$ of a cell suspension containing $5 \times 10^{6}$ cells per $\mathrm{ml}$ of $17 \mathrm{~mm}$ phosphate buffer were slowly swirled in a $1-1$. flask. At various times $3-\mathrm{ml}$ samples were removed and centrifuged to pellet the clumps which had formed. The supernatants were assayed for $\mathrm{NH}_{3}+\mathrm{NH}_{4}+$ by Nessler's reagent $(\bullet)$. Dilutions of the supernatants were made with fresh medium and $1 \mathrm{ml}$ of each dilution was put into wells. $5 \times 10^{6}$ freshly harvested cells were added to each well. The biological activity of each sample is indicated by the reciprocal of the greatest dilution which stimulated significant spore differentiation $(O)$.

Table 2. Loss of biological activity by heating conditioned medium

\begin{tabular}{cccc}
\hline $\begin{array}{c}\text { Conditioned } \\
\text { medium }\end{array}$ & $\begin{array}{c}\text { Open vessel, } \\
\mathrm{pH} 8 \cdot 0\end{array}$ & $\begin{array}{c}\text { Open vessel, } \\
\mathrm{pH} 5 \cdot 0\end{array}$ & $\begin{array}{c}\text { Closed vessel, } \\
\mathrm{pH} 8 \cdot 0\end{array}$ \\
\hline 8 & $\mathrm{I}$ & 8 & - \\
$(29 \mathrm{mM})$ & $\begin{array}{c}(0.4 \mathrm{mM}) \\
16\end{array}$ & $(28 \mathrm{mM})$ & 8 \\
$(24 \mathrm{mM})$ & $(0.2 \mathrm{mM})$ & - & $(22 \mathrm{mM})$
\end{tabular}

Conditioned medium was heated at $55^{\circ} \mathrm{C}$ for $2 \mathrm{~h}$ either in an open container at $\mathrm{pH} 8.0$ or $\mathrm{pH} 5^{\circ} \mathrm{O}$ or in a sealed tube at $\mathrm{pH} 8 \cdot 0$. Following treatment, $\mathrm{NH}_{3}+\mathrm{NH}_{4}+$ in each sample was determined by Nessler's reagent (values in parentheses). Dilutions of each sample were made and tested for biological activity. The biological activity is expressed as the reciprocal of the greatest dilution which stimulated significant spore differentiation. Results of 2 independent experiments are shown.

$\mathrm{NH}_{3}+\mathrm{NH}_{4}+$ is present as volatile $\mathrm{NH}_{3}$ ). These treatments showed no loss of $\mathrm{NH}_{3}+\mathrm{NH}_{4}^{+}$and little if any loss of activity. Thus, conditions which removed $\mathrm{NH}_{3}+\mathrm{NH}_{4}^{+}$also removed the differentiation-stimulating activity from conditioned medium.

To determine if the loss of biological activity was due specifically to the loss of $\mathrm{NH}_{3}+\mathrm{NH}_{4}^{+}$, attempts were made to reconstitute the activity of conditioned medium 
by adding ammonia to dilutions of ammonia-free (heated) conditioned medium. The concentration of $\mathrm{NH}_{3}+\mathrm{NH}_{4}+$ in each dilution was adjusted to the same concentration present in the dilutions of untreated conditioned medium. The addition of $\mathrm{NH}_{3}+\mathrm{NH}_{4}{ }^{+}$almost completely restored the differentiation-stimulating activity (Table 3). It is clear from these results that $\mathrm{NH}_{3}+\mathrm{NH}_{4}{ }^{+}$is an active component of conditioned medium.

Table 3. Reconstitution of biological activity with $\mathrm{NH}_{3}+\mathrm{NH}_{4}^{+}$

\begin{tabular}{ccc}
\hline $\begin{array}{c}\text { Conditioned } \\
\text { medium }\end{array}$ & $\begin{array}{c}\text { Ammonia-free } \\
\text { conditioned } \\
\text { medium }\end{array}$ & $\begin{array}{c}\text { Ammonia-free } \\
\text { conditioned } \\
\text { medium plus } \\
\mathrm{NH}_{4} \mathrm{Cl}\end{array}$ \\
\hline 8 & $<\mathrm{I}$ & 4 \\
8 & $<2$ & 8 \\
16 & $<$ & 8
\end{tabular}

Conditioned medium was heated at $55^{\circ} \mathrm{C}$ and $\mathrm{pH} 8.0$ for $2 \mathrm{~h}$ to remove the $\mathrm{NH}_{3}+\mathrm{NH}_{4}{ }^{+}$. Two sets of 2 -fold dilutions of the ammonia-free medium were made. To one set sufficient $\mathrm{NH}_{4} \mathrm{Cl}$ was added to each dilution to restore the same concentration of $\mathrm{NH}_{3}+\mathrm{NH}_{4}+$ present in each of the dilutions of untreated conditioned medium. The biological activity is expressed as the reciprocal of the greatest dilution which stimulated significant spore differentiation. The results of 3 independent experiments are shown.

Table 4. Percentage spore differentiation in dilutions of conditioned medium and conditioned medium plus $\mathrm{NH}_{4} \mathrm{Cl}$

\begin{tabular}{ccc}
\hline Dilutions & $\begin{array}{c}\text { Conditioned } \\
\text { medium } \\
(\%)\end{array}$ & $\begin{array}{c}\text { Conditioned } \\
\text { medium }+6 \mathrm{mM} \\
\mathrm{NH}_{4} \mathrm{Cl} \\
(\%)\end{array}$ \\
\hline $1 / 2$ & 0 & $<\mathrm{I}$ \\
$\mathrm{I} / 4$ & 20 & 20 \\
$1 / 8$ & $20-30$ & $10-20$ \\
$1 / 16$ & $20-30$ & 20 \\
$1 / 32$ & 0 & $20-30$ \\
$1 / 64$ & 0 & $<\mathrm{I}$
\end{tabular}

Two sets of dilutions of conditioned medium were made in Linbro wells. $6 \mathrm{mM} \mathrm{NH}_{4} \mathrm{Cl}$ was added to each dilution of one set. $5 \times 10^{6}$ cells were added to the wells. After $2 \mathrm{I}$ h the clumps which formed were squashed and examined for spores. In this experiment, $6 \mathrm{mM} \mathrm{NH} \mathrm{NH}_{4} \mathrm{Cl}$ fresh buffer did not induce any spore differentiation.

\section{Evidence for a second factor}

While $\mathrm{NH}_{3}+\mathrm{NH}_{4}{ }^{+}$alone stimulated little activity, when combined with ammoniafree conditioned medium it resulted in extensive differentiation. This strongly suggests that there is another factor in conditioned medium which is necessary in addition to $\mathrm{NH}_{3}+\mathrm{NH}_{4}{ }^{+}$. This factor also can be demonstrated by adding an optimum concentration of $\mathrm{NH}_{3}+\mathrm{NH}_{4}+$ to dilutions of untreated conditioned medium. It was 
consistently found that the added $\mathrm{NH}_{3}+\mathrm{NH}_{4}{ }^{+}$extended the range of activity of conditioned medium by one further 2 -fold dilution (Table 4 ). This indicates that the second factor(s) is present in conditioned medium at twice the potency of $\mathrm{NH}_{3}+\mathrm{NH}_{4}{ }^{+}$.

The existence of a second factor raised the possibility that both $\mathrm{NH}_{3}+\mathrm{NH}_{4}{ }^{+}$and the second factor, together, are necessary for differentiation. The low activity observed when $\mathrm{NH}_{3}+\mathrm{NH}_{4}{ }^{+}$was added to fresh medium might actually be due to the exogenous $\mathrm{NH}_{3}+\mathrm{NH}_{4}{ }^{+}$plus the second factor which accumulated during the course of the assay. 'The activity of $\mathrm{NH}_{3}+\mathrm{NH}_{4}{ }^{+}$, therefore, was tested in 'transfer' experiments similar to the one in Fig. 3 B. Under these conditions $\mathrm{NH}_{3}+\mathrm{NH}_{4}{ }^{+}$was not active in stimulating differentiation. Thus, differentiation in submerged clumps is dependent on both $\mathrm{NH}_{3}+\mathrm{NH}_{4}{ }^{+}$and a second factor secreted by the cells.

\section{DISCUSSION}

It has been previously reported that submerged clumps of Dictyostelium cells differentiate into stalk cells and spores under an oxygen atmosphere (Sternfeld \& Bonner, 1977). Here, it is shown that at least 2 factors are released by the cells and that both, together, are required for differentiation. One of the factors is ammonia $\left(\mathrm{NH}_{3}+\mathrm{NH}_{4}+\right)$. The other factor(s) is heat stable and dialysable but has not yet been further characterized. The factors can be collected in a conditioned medium and, when added to cells, stimulate differentiation. Conditioned medium loses its biological activity upon removal of the $\mathrm{NH}_{3}+\mathrm{NH}_{4}{ }^{+}$. When $\mathrm{NH}_{3}+\mathrm{NH}_{4}+$ is added back, activity is restored. Because $\mathrm{NH}_{3}+\mathrm{NH}_{4}{ }^{+}$, alone, has no activity, a second factor(s) in the conditioned medium is required for differentiation. Calcium, when present in the medium, was found to delay and inhibit the amount of differentiation which took place. The relative roles of $\mathrm{NH}_{3}$ and $\mathrm{NH}_{4}{ }^{+}$as differentiation factors are not yet clear. Since the biological activity of conditioned medium is about the same from $\mathrm{pH} 6.0$ to $\mathrm{pH} 7 \cdot \circ$ (unpublished results) $\mathrm{NH}_{4}+$ may be the active component.

\section{Factors affecting differentiation in Dictyostelium}

Several differentiation-stimulating factors have been described for early stages in the life cycle of Dictyostelium. cAMP, if added in advance of its normal time of appearance caused precocious differentiation (Darmon, Brachet \& Pereira da Silva, I975) including the early production of phosphodiesterase (Klein, I975) and contact sites A (Gerisch, Fromm, Huesgen \& Wick, 1975). Phosphodiesterase has been found to induce the early onset of aggregation (Alcantara \& Bazill, 1976; Wier, 1977). Both PDE and cAMP (added once at the beginning of the experiments) have been tested in our system and neither stimulates differentiation. The inhibition of differentiation by calcium, however, may act at this early stage of development as Klein (1976) reports that calcium inhibits Dictyostelium adenylate cyclase.

A diffusible factor secreted by cells is required for induction of stalk cells on agar containing cAMP (Town et al. 1976). Also, under these conditions limited spore differentiation can be induced in one class of mutants. It is unlikely that the second 
factor reported here is the same factor that Town and his co-workers have isolated. First, the factor they isolated cannot be collected from a cell suspension, but must be collected through a dialysis membrane (Town, personal communication). Secondly, our conditioned medium has no activity in Town's system (Town, personal communication).

Grabel \& Loomis ( 1978 ) reported that the appearance of $N$-acetylglucosaminidase can be accelerated in a cell suspension by a small, heat stable molecule(s) released by the cells. This factor may be ammonia as it is also stable to proteolytic enzymes and mild acid hydrolysis.

\section{Effects of ammonia on slime mould development}

It has long been known that slime moulds produce ammonia (Gregg et al. 1954). Also, ammonia has been shown to affect various aspects of slime mould development (Feit, 1969). Differentiation of microcysts in Polysphondylium pallidum is induced by ammonia (Lonski, 1976). Microcyst formation is an expression of an alternative pathway of differentiation in which all of the amoebae form round, spore-like, resistant cells. It is interesting that in another organism, Penicillium, ammonia is rapidly assimilated by the mycelium upon induction of sporulation (Morton, I96r). Thadani, Pan \& Bonner (1977) have shown that ammonia and cAMP play antagonistic roles in the regulation of aggregation territory size. The decision of whether an aggregate will form a slug or a fruiting body may also be controlled by opposing actions of cAMP and ammonia (Schindler \& Sussman, 1977). These authors showed that the effect of ammonia is to prolong the undifferentiated slug stage. While this finding seems to conflict with those presented in this paper, no simple explanation is immediately apparent.

The facts that cAMP and ammonia appear to play antagonistic roles, that cAMP is necessary for stalk differentiation, and that ammonia can stimulate microcyst differentiation raises the possibility that ammonia is required for spore differentiation in normal development. Ammonia is apparently produced throughout development and probably by stalk cells in particular during culmination (Gregg et al. 1954). As long as cells are in contact with the agar substratum the $\mathrm{NH}_{3}+\mathrm{NH}_{4}+$ concentration near the cells is expected to be low since the agar acts as a large diffusion sink. However, during culmination, diffusion of $\mathrm{NH}_{3}+\mathrm{NH}_{4}{ }^{+}$would be severely limited as the cell mass lifts off the agar surface. Under these conditions $\mathrm{NH}_{3}+\mathrm{NH}_{4}+$ could only be lost by evaporation of $\mathrm{NH}_{3}$. Loss of $\mathrm{NH}_{3}$ by evaporation, however, must be negligible as sori are acidic and evaporation of $\mathrm{NH}_{3}$ at $20^{\circ} \mathrm{C}$ below $\mathrm{pH} 8.0$ is very slow (unpublished results).

The measurements of the $\mathrm{NH}_{3}+\mathrm{NH}_{4}{ }^{+}$accumulated during development presented here and by Schindler \& Sussman (1977) can be used to calculate the $\mathrm{NH}_{3}+\mathrm{NH}_{4}{ }^{+}$ concentration which might be expected in a fruiting body. Even if only a fraction of the cells in the fruiting body are producing ammonia, it is likely that more than enough $\mathrm{NH}_{3}+\mathrm{NH}_{4}{ }^{+}$accumulates during culmination to provide $\mathrm{NH}_{3}+\mathrm{NH}_{4}{ }^{+}$concentrations in the sorus that are similar to concentrations effective in our submerged system. 
The authors thank J. T. Bonner, S. C. Kayman, and P. M. Silverman for helpful discussions and critical reading of the manuscript. The research was supported by grants from the NIH (GM II 301 ) and the NSF (77-25426). C.N.D. is a recipient of a Career Development Award (FRA-132) from the American Cancer Society.

\section{REFERENCES}

Alcantara, F. \& Bazill, G. (I976). Extracellular cyclic AMP-phosphodiesterase accelerates differentiation in Dictyostelitu discoideum. $\mathscr{~}$. gen. Microbiol. 92, 35I.

Bonner, J. T. (1947). Evidence for the formation of cell aggregates by chemotaxis in the development of the slime mold Dictyostelium discoideum. Y. exp. Zool. 106, 1-26.

BONNER, J. 'T. (1970). Induction of stalk cell differentiation by cyclic AMP in the cellular slime mold Dictyostelium discoideum. Proc. natn. Acad. Sci. U.S.A. 65, I 10-1 I 3.

Bonner, J. T. (r97I). Aggregation and differentiation in the cellular slime molds. A. Rev. Microbiol. 25, 75-92.

Darmon, M., Brachet, P. \& Pereira da Silva, L. (1975). Chemotactic signals induce cell differentiation in Dictyostelium discoideum. Proc. natn. Acad. Sci. U.S.A. 72 (8), 363-366.

FeIT, I. N. (1969). Evidence for the Regulation of Aggregate Density by the Production of Ammonia in the Cellular Slime Molds. Ph.D. Thesis, Princeton University.

Fischer, R. B. \& Peters, D. G. (I968). Basic Theory and Practice of Quantitative Chemical Analysis, 3rd edn, pp. 657-658,677-678. Philadelphia: Saunders.

Forman, D. \& Garrod, D. R. (1977). Pattern formation in Dictyostelium II: Differentiation and pattern formation in non-polar aggregates. F. Embryol. exp. Morph. 40, 229-243.

Gerisch, G., Fromm, H., Huescen, A. \& Wick, U. (i975). Control of cell-contact sites by cyclic AMP pulses in differentiating Dictyostelium cells. Nature, Lond. 225, 547-549.

GraBel, L. \& LoOMis, W. F. (1978). Effector controlling accumulation of $N$-acetylglucosaminidase during development of Dictyostelium discoideum. Devl Biol. 64, 203-208.

GregG, J. H., Hackney, A. L. \& Krivanek, J. O. (1954). Nitrogen metabolism for the slime mold Dictyostelium discoideum during growth and morphogenesis. Biol. Bull. mar. biol. Lab., Woods Hole ro7, 226-235.

KLEIN, C. (1975). Induction of phosphodiesterase by cyclic adenosine $3^{\prime}, 5^{\prime}$-monophosphate in differentiating Dictyostelium discoideum amoebae. $\mathcal{Y}$. biol. Chem. 250, 71 34-7 138.

KLEIN, C. (1976). Adenylate cyclase activity in Dictyostelium discoideum amoebae and its changes during differentiation. FEBS Letters, Amsterdam 68 (1), 125-128.

LoNSKI, J. (1976). The effect of ammonia on fruiting body size and microcyst formation in the cellular slime molds. Devl Biol. 51, 158-165.

Morton, A. G. (1961). The induction of sporulation in mould fungi. Proc. R. Soc. B I53, 548-569.

Schindler, J. \& Sussman, M. (1977). Ammonia determines the choice of morphogenesis pathways in Dictyostelium discoideum. I. molec. Biol. 116, 161-169.

Sternfeld, J. \& Bonner, J. T. (1977). Cell differentiation in Dictyostelium under submerged conditions. Proc. natn. Acad. Sci. U.S.A. 74 (1), 268-27 I.

Takeuchi, I., Hayashi, M. \& Tasaka, M. (1977). Cell differentiation and pattern formation in Dictyostelium discoideum. In. Development and Differentiation in the Cellular Slime Moulds (ed. P. Cappuccinelli \& J. M. Ashworth), pp. I-16. Amsterdam: Elsevier/North-Holland.

Thadani, V., Pan, P. \& Bonner, J. T. (1977). Complementary effects of ammonia and cAMP on aggregation territory size in the cellular slime mold Dictyostelizm mucoroides. Expl Cell Res. 108, 75-78.

Town, C. D., Gross, J. D. \& Kay, R. R. (1976). Cell differentiation without morphogenesis in Dictyostelium discoideum. Nature, Lond. 262, 717-719.

WIER, P. W. (1977). Cyclic AMP, cyclic AMP phosphodiesterase, and the duration of the interphase in Dictyostelium discoideum. Differentiation 9, $183-191$.

Wurster, B., Schubiger, K., Wick, U. \& Gerisch, G. (1977). Cyclic GMP in Dictyostelium discoideum: Oscillations and pulses in response to folic acid and cyclic AMP. FEBS Letters, Amsterdam 76, 141.

(Received 3 Fanuary 1979) 
